DOI: https://doi.org/10.34069/AI/2021.45.09.6

How to Cite:

Andrusiv, U., Kossak, V., Mykhayliv, M., Fedina, N., \& Zabzaliuk, D. (2021). Grounds and consequences of waiver of the contract on the provision of tourist services. Amazonia Investiga, 10(45), 63-72. https://doi.org/10.34069/AI/2021.45.09.6

\title{
Grounds and consequences of waiver of the contract on the provision of tourist services
}

\section{Підстави та наслідки відмови від договору про надання туристичних послуг}

Received: August 1, 2021

Abstract

The purpose of the article is to clarify the legal nature, grounds, realization mechanism and consequences of waiver of the contract on the provision of tourist services. The research was conducted using such methods of scientific knowledge as dialectical, comparative, formallegal, logical-legal. Based on the analysis of doctrinal approaches and regulations, it is established that the refusal of the agreement on the provision of tourist services is a measure of operational influence and a means of protecting the civil interest. The grounds for unilateral waiver of the contract differentiated into unconditional and those that are a consequence of violation of its terms. At the same time, it is stated that this subjective right is exercised in out-of-court procedure by sending a written (electronic) notice to the counterparty. In the context of the COVID-19 pandemic, it is proposed to give tourists the opportunity to choose between postponing the trip to another term and exercising withdrawal from the agreement. Particular attention is paid to the
Accepted: September 23, 2021

Written by:

Uliana Andrusiv ${ }^{19}$

https://orcid.org/0000-0003-2300-5114

Volodymyr Kossak ${ }^{20}$

https://orcid.org/0000-0002-8699-9200

Mariya Mykhayliv ${ }^{21}$

https://orcid.org/0000-0002-1702-7432

Nataliia Fedina ${ }^{22}$

https://orcid.org/0000-0002-7521-9635

Dmytro Zabzaliuk ${ }^{23}$

https://orcid.org/0000-0002-1041-0148

\begin{abstract}
Анотація
Метою статті є з'ясування правової природи, підстав, механізму реалізації та наслідків односторонньої відмови від договору про надання туристичних послуг. Дослідження проведено із використанням таких методів наукового пізнання як діалектичний, порівняльний, формально-юридичний, логіко-юридичний. На підставі аналізу доктринальних підходів та нормативних приписів встановлено, що відмова від договору про надання туристичних послуг $\epsilon$ заходом оперативного впливу та засобом захисту цивільного інтересу. Підстави односторонньої відмови від договору диференційовано на безумовні та такі, що $є$ наслідком порушення його умов. Водночас констатовано, що це суб'єктивне право реалізується у позасудовому порядку, шляхом скерування контрагенту повідомлення в письмовій (електронній) формі. В умовах пандемії COVID-19 запропоновано надати туристу можливість обирати між перенесенням подорожі на
\end{abstract}

\footnotetext{
${ }^{19}$ Candidate of Law, Associate Professor, Associate Professor of the Civil Law Disciplines Department, Institute of Law, Lviv State University of Internal Affairs, Lviv, Ukraine.

${ }^{20}$ Doctor of Law, Professor, Head of the Civil Law and Process Department, Faculty of Law, Ivan Franko National University of Lviv, Lviv, Ukraine.

${ }^{21}$ Candidate of Law, Associate Professor, Associate Professor of the Civil Law and Process Department, Faculty of Law, Ivan Franko National University of Lviv, Lviv, Ukraine.

${ }^{22}$ Candidate of Law, Associate Professor of the Theory of Law, Constitutional and Private Law Department, Institute of Specialist Training for National Police Units, Lviv State University of Internal Affairs, Lviv, Ukraine.

${ }^{23}$ Doctor of Law, Associate Professor, Head of the General Legal Disciplines Department, Institute of Law, Lviv State University of Internal Affairs, Lviv, Ukraine.
} 
general and special consequences of lawful refusal. Based on the study, the authors made generalizations and conclusions about the state and prospects of improving the mechanism for exercising the right to unilateral waiver of the contract on the provision of tourist services.

Key words: contract on the provision of tourist services, unilateral waiver of the contract, measure of operative influence, means of protection of civil interest, legal and factual grounds, termination of the agreement, actually incurred costs.

\section{Introduction}

Tourism, as a generator of economic growth of the state, is an important part of modern people life. The key legal mean of achieving the main goal of tourism, which is to provide tourists with quality tourist services, is a civil agreement.

The purpose of the article is to clarify the legal nature, grounds, realization mechanism and consequences of unilateral refusal of contractual obligations that mediate the provision of tourist services, identify shortcomings in the legal regulation of this institution and make suggestions for their elimination.

When concluding an agreement on the provision of tourist services, it is impossible to predict all possible scenarios. In practice, there are often cases when in certain circumstances the execution of the agreement becomes impossible or one of the parties loses interest in it. In order to normalize such situations and prevent negative consequences for the contractors of the contractual obligation, the institution of waiver of the contract is enshrined in law.

Refusal of the agreement is a fairly common reason for termination of obligations on provision of travel services. The application of this institute became especially important in the conditions of the COVID-19 coronavirus pandemic, when due to the established restrictions on movement and closing of borders tourists are forced to refuse the ordered and paid tourist services.

However, the mechanism of realization of the right to unilateral waiver of the contract on the provision of tourist services, the consequences of such actions in practice create serious obstacles associated with insufficient elaboration of these інший строк та відмовою від договору. Особливу увагу приділено загальним та спеціальним наслідкам правомірної відмови. На основі проведеного дослідження авторами зроблені узагальнення та висновки щодо стану та перспектив удосконалення механізму реалізації права на односторонню відмову від договору про надання туристичних послуг.

Ключові слова: договір про надання туристичних послуг, одностороння відмова від договору, захід оперативного впливу, засіб захисту цивільного інтересу, юридичні та фактичні підстави, розірвання договору, фактично понесені витрати.

issues, as well as incompleteness and inconsistency of legal norms.

In view of this, issues related to the termination of contractual obligations on provision of tourist services due to the refusal of them need deep scientific and theoretical comprehension and solutions.

\section{Literature review}

Problematic issues of legal regulation of tourism relations, in particular contractual constructions used in the field of tourism, have repeatedly been the subject of scientific research of Ukrainian and foreign civilians. A significant contribution to the study of contractual obligations for the provision of tourist services made in their dissertations V. O. Kokhanovskyi (2018), R. I. Yavorskyy (2015). However, scholars have focused on elucidating their legal nature, content, and termination. The issue of lawful unilateral refusal of the agreement on the provision of tourist services, as a legal basis for changing or terminating the contractual relationship, has not received adequate coverage.

At the general theoretical level, regardless of the specifics of tourist services, the institution of waiver has been studied by such scientists as L. M. Baranova (2015), T. V. Bodnar (2012), R. V. Grynko (2014), I. V. Spasibo-Fateeva (2021), G. O. Urazova (2015), etc.

The absence of special scientific investigations, which would comprehensively consider the features of unilateral waiver from the agreement on the provision of tourist services, causes legal uncertainty at the stage of law enforcement, which is reflected in the controversial legal 


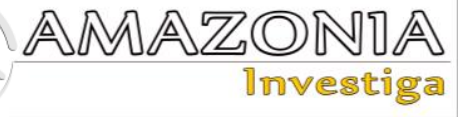

nature of the refusal, distinguishing of this category from other grounds for termination of obligation, which mediates the provision of tourist services, as well as in determining the grounds and consequences of refusal of it.

Based on the above, we conclude that a comprehensive theoretical and applied generalization of the application features of the institution of refusal of the contract on the provision of tourist services is urgent and necessary.

\section{Methodology}

In the process of research, general and special methods of scientific cognition are used in their combination. The dialectical method helped to reveal the grounds and consequences of the waiver of the contract on the provision of tourist services. With its help, we differentiated the legal and factual grounds of the refusal, and also established that the general consequence of the exercise of this right is the change or termination of a binding legal relationship.

Using such logical techniques as synthesis and analysis, we found that by its legal nature, the waiver of the contract is a unilateral lawful action of the authorized party. Depending on whether the application of the waiver is associated or not related to breach of contract, it should be interpreted as a measure of operational influence or a means of protection of civil interest.

The use of the formal-legal method contributed to the disclosure of the mechanism for exercising the right of the refusal of the contract for the provision of tourist services and the separation of its constituent elements. Thus, we have established that the party who waives of the contract exercises this subjective right by sending a notice to the counterparty without recourse to the authorities.

The comparative-legal method was used in a comparative analysis of Ukrainian legislation that governs tourism relations with the legal field of foreign countries and the European Union. As a result, it is proposed to implement in national legislation alternative mechanisms for reimbursement of package tours in a state of emergency, in particular the COVID-19 pandemic.

The logical-legal method helped to formulate the conclusions and generalizations and to determine the consistency of the expressed judgments and concepts. Thus, this method allowed us to summarize that the institution of waiver of the contract for the provision of tourist services is one of the effective mechanisms for protecting the rights and legitimate interests of participants in tourism relations.

\section{Results and discussion}

The concept and legal nature of the institution of waiver of the contract on the provision of tourist services

Refusal of the agreement must be understood as defined by law or contract the possibility of a person to commit a conscious lawful action aimed at achieving organizational and legal consequences, ie termination or change of the contractual relationship, without recourse to the authorized jurisdictional body.

General provisions on waiver of the contract are regulated by Art. 651 of the Civil Code of Ukraine. As follows from the provisions of Part 3 of this rule, the agreement may be terminated in the event of unilateral waiver of the contract in full or in part, if the right to such waiver is established by agreement or law. This regulation corresponds to Art. 310, 525 of the Civil Code of Ukraine, which enshrines the prohibition of unilateral waiver of obligations, its execution, except when the right to such waiver is established by agreement or law (Law No. 43515, 2003).

One of such exceptions is regulated in a special law governing tourism relations. In particular, Art. 20 of the Law of Ukraine «On Tourism» (Law No. 324/95-BP, 1995) provides the possibility of each of the parties to the contract on the provision of tourist services to unilaterally refuse to execute it or to require changes to it.

A number of European countries also use legal constructions, which are analogous to the unilateral refusal of a contractual obligation in the field of tourist services. For example, the right to withdraw from the package travel contract is provided in Art. L211-14 of the French Tourism Code (Law No. 92-1341, 1992), $\S 651 \mathrm{~h}$ of the Civil Code of the Federal Republic of Germany (Law No. 2909, 2002), Art. 41 Legislative decree No 62 of the Italian Republic (2018).

By its legal nature, a unilateral refusal to execution of an agreement is a legal fact in which the unilateral expression of the will of the authorized party is sufficient to change or terminate the contractual obligation. This legal 
fact should be interpreted as a simultaneous waiver of rights and obligations.

We support the position of those scholars who, given the nature of the will of the entity exercising the right to unilateral withdrawal from agreement, as well as the consequences of such refusal, qualify it as a unilateral legal act (Bodnar, 2012; Baranova, 2015).

In the case of unilateral refusal, the authorized party has a subjective civil right, which is dominated by the right to lawful active action to terminate or unilaterally change the rights and obligations of the parties to the contractual obligation. That is, for the commission of such a legal act it is sufficient to have a civil interest of only one party of the contract, which by law or agreement is endowed with the right to change or terminate the legal relationship unilaterally. This right corresponds to the obligation of the passive party not to interfere with its realization.

A. B. Grinyak (2013), disclosing the legal nature of unilateral waiver of contract, emphasizes the expediency of defining the right to unilateral refusal as secondary rights, as the creditor's right does not correspond to a clearly defined obligation of the debtor, so the latter must only «suffer» actions of the creditor on realization of the right and their corresponding consequences.

That is, the secondary right of the tourist is the possibility of his active behavior associated with the waiver to voyage and the ability to demand a refund of the paid contract price.

The exercise of this subjective right does not require the filing of a lawsuit to annulment or amend the agreement. Therefore, by this unilateral legal act, the agreement is changed or terminated without recourse to a jurisdictional body, ie out-of-court settlement.

\section{Grounds and procedure for exercising the right to waiver of the contract on the provision of tourist services}

The exercise of the right to unilaterally refusal of the agreement on the provision of tourist services is expressed through active conduct. The party who decides to waiver of the contract must notify the other party. Such notification is a constitutive element of the mechanism of realization of this subjective right.

It is necessary to emphasize that although the will of the party who are refusal of the contract must be accepted by the counterparty, but its consent to change or terminate the agreement is not required.

It is not established at the legislative level in what way and in what form the counterparty is notified about the refusal. In this regard, it is appropriate to support the opinion expressed in the literature that such a message should be made in written form (Yavorskyy, 2015), including the use of means of electronic communication.

The legislator has not determined the moment from which the contract, which was unilaterally refused by one of the parties, is considered amended or terminated.

The prevailing approach among experts in civil law is that the contract terminates from the moment of informing the counterparty under the agreement about the decision of another party to waiver of contract in due form (Grynko, 2014). It is noteworthy that the notice of refusal acquires legal significance from the moment of its receipt by the addressee, ie, as rightly noted by G. O. Urazova (2015), the principle of «delivery» is to be applied.

Therefore, in case of unilateral waiver of one of the parties of the contract on the provision of tourist services, the contractual relationship is considered changed or terminated from the moment when the counterparty found out about such refusal, ie received the appropriate notice.

Taking into account the above, we reach a reasonable conclusion that the mechanism for exercising the right to withdrawal from the contract on the provision of tourist services includes the following components: out-of-court procedure for changing or terminating the contractual obligation; the party who refusal of the contract notifies the counterparty by sending a notice in written (electronic) form; the contractual relationship is considered changed or terminated from the moment of receipt of the notice by the other party.

From the systematic analysis of the provisions of Article 20 of the Law of Ukraine «On Tourism» (Law No. 324/95-VR, 1995) it is seen that the legislator identifies three grounds for refusal of a tourist of the contract on the provision of tourist services. Thus, the tourist is guaranteed the opportunity to refusal of the agreement in case of increase in the price of the tourist product by 5 percent compared to the original price. Also, the customer has the right to waiver of the contract without compensation to the tour operator (travel agent) in connection with changes in the essential 


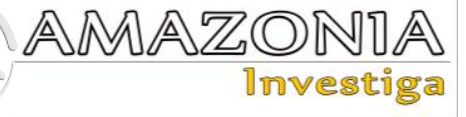

terms of the agreement and the circumstances that guided them during the concluding of the contract. In addition, the tourist may refuse to execute the contract before the trip (regardless of the reason for such refusal) subject to reimbursement to the tour operator (travel agent) of the actually incurred documented expenses related to the refusal.

With regard to the latter prerequisite for the waiver of the tourist of the contract on the provision of tourist services, it should be noted that in accordance with Art. 12 of the EU Directive on package travel and linked travel arrangements (Directive No. 2015/2302, 2015) the traveler also has a analogous right to terminate the contract unilaterally at any time before the start of the trip. In addition, by notifying the organizer (tour operator) no later than seven days before the start of the package tour, he has the right to transfer the rights and obligations under the contract to another person (Art. 9). A similar provision is in Art. 651e of the Civil Code of the Federal Republic of Germany (Law No. 2909, 2002).

Unfortunately, it should be noted that at the national level such a provision has not been regulated. In our opinion, the legislative enshrinement of such a subjective right for tourists will not only help create legal guarantees to protect their interests, but also will help protect against possible conflict situations and will ensure compliance with the requirement of «quality» of the law as one of the integral elements of the rule of law (Maikut, Andrusiv, Yurkevych, Dutko, \& Zaiats, 2020).

At the same time, the tour operator or travel agent has the right to withdrawal from the agreement only if the tourist is fully reimbursed for damages caused by the termination of the contract, confirmed in the prescribed manner, unless it was the fault of the tourist. In the above cases, the refusal of the agreement on the provision of tourist services is the right of the party, which it exercises at its discretion.

Refusal of the agreement on the provision of tourist services is characterized by certain features. Yes, it can be unconditional or caused by a breach of obligations by one of the counterparties, if it is provided by contract or law.

In the specialized literature, it is well-established that unilateral waiver of the contract can be an independent ground for its termination only in cases where such a refusal does not require any legal fact («unconditional refusal») (SpasiboFateeva, (Ed.) 2021). The provisions of Part 10 of Art. 20 of the Law of Ukraine «On Tourism» visually illustrate the unconditional refusal, which implies that a tourist may at any time waiver of the agreement without stating the reason, ie the reasons for such expression of will have no legal significance.

However, in most cases, the exercise of the analyzed subjective right requires a legal fact, which may be an action (for example, an increase by tour operator of the price of a tourist product by 5 or more percent) or an event (for example, a significant change in circumstances).

According to such a criterion as reason for occurrence the waiver of the contract on the provision of tourist services should be differentiated into:

- waiver, which applies regardless of the breach of contract by the counterparty and any other circumstances.

Legitimate prerequisites for such a legal action are regulated by Art. 907 of the Civil Code of Ukraine, which enshrines the right to unilateral waiver of the contract on the provision of services, which is not related to the breach of agreement by another party. This general rule is detailed in Art. 20 of the Law of Ukraine «On Tourism», which describes the possibility of a tourist to refusal of the agreement due to a significant change in circumstances, as well as unconditional refusal. In these cases, the waiver of the contract must be qualified as one of the means of civil protection of the legitimate interest of the authorized party, the existence of which is not related to the likelihood of the offense and the presence of any circumstances (factors)

- refusal of the authorized party, which is a consequence of breach of obligations by the counterparty.

The right to unilateral waiver, as one of the legal consequences of breach of obligation, is provided by the provisions of Art. 611, 615 of the Civil Code of Ukraine. Such refusal shall apply only in cases established by contract or law.

In case of breach of the obligation by the party, the waiver of the agreement should be considered as a measures of operational influence, which in the doctrine means legal measures of law enforcement nature, provided by law or agreement, applied in contractual obligations to 
the person who violated or poses a real threat of breach of civil rights and obligations directly by the authorized person without recourse to the protection of the right to the relevant state bodies (Polnyi, 2020). Given that such remedies are used by the party to the agreement which is entitled to refuse independently without recourse to the jurisdictional body, they belong to the methods of self-defense.

In obligations on the provision of tourist services in the event of their unilateral termination there are such ways of self-defense as change or termination of the legal relationship.

The above allows us to state that the tourist can exercise the right to refuse both in case of breach of agreement by the counterparty, and when the refusal is not related to the fact of breach. In the first case, the refusal should be interpreted as a measures of operational influence on the violator, ie self-defense of civil law, and in the second - a means of protecting the civil interest of the party entitled to refuse.

It should be noted that experts, considering the grounds for waiver, rightly differentiate them into legal (enshrined in the Civil Code of Ukraine and special legislation rules or terms of the contract) and factual (specific circumstances, the presence of which entitles the authorized party to waiver of the contract) (Lukasevych-Krutnyk, 2019). Both of these grounds create legitimate preconditions for the exercise of the right to withdrawal from the contract on the provision of tourist services.

\section{Features of realization by the tourist of the right to waiver of the contract in the conditions of a coronavirus COVID-19}

In the context of the researched issue, the question arises about the possibility of realization of a tourist's right to waiver of the contract on the provision of tourist services in a coronavirus pandemic. The COVID-19 pandemic has changed the established world order, affecting all spheres of public life, including tourism.

It should be noted that the Ukrainian legislation does not provide special mechanisms for the protection of tourists in extraordinary circumstances, in particular in terms of ensuring their safety, and does not regulate the possibility of unilateral refusal of the customer to execute the agreement in case of their occurrence. Tour operators, based on force majeure - the establishment of quarantine due to the spread of coronavirus COVID-19, offer consumers of travel services only one option - postponement of travel, refusing to return the money. Therefore, customers of travel services can terminate the contract only in court.

In our opinion, under the current circumstances, when tourists are forced to cancel tourist trips due to restrictions imposed worldwide, they should be given alternative rights like to refuse a tourist trip without compensating the tour operator and refund all funds for the unprovided service, or to postpone the date of travel to a later date.

This approach correlates with the provisions of Art. 12 (2) of EU Directive No. 2015/2302 (2015), which states that the traveler shall have the right to terminate the package travel contract before the start of the package without paying any termination fee in the event of unavoidable and extraordinary circumstances occurring at the place of destination or its immediate vicinity and significantly affecting the performance of the package, or which significantly affect the carriage of passengers to the destination.

In the current situation with the coronavirus pandemic, the European Commission suggests EU Member States to take a common approach, giving tourists whose package travel and transport services have been canceled the right to choose between a refund and other forms of reimbursement, including vouchers for future trips (European Commission, 2020).

In addition, some EU Member States have introduced alternative mechanisms for reimbursing package tours, which customers (tourists) can claim after the termination of an contract in connection with a coronavirus pandemic. In Italy in Law Decree no. 9 of March 2, 2020 and in France in Order 2020-315 of March 25, 2020 such special alternative means of protection include: refund to the traveler full amount of money paid under the package tour contract; issuance of a voucher which can be used within a specified period; replacement of a package tour with another package of equivalent or higher quality (De Berti Jacchia Franchini Forlani Studio Legale, 2020).

Given the above, in order to make formal and legal certainty in these relations, as well as to ensure the effective realization of the tourist's right to unilaterally waiver of the agreement and prevent abuse by tourism entities, we consider it appropriate at the legislative level to enshrine the following provisions: «In the event of circumstances that indicate the emergence in the 


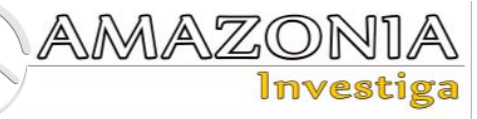

country (place) of temporary stay of the tourist or in the immediate vicinity of the threat to the safety of his life or health, as well as extraordinary circumstances that do not depend on the tourist and make it impossible to travel, he has the right to waiver of the agreement on the provision of tourist services (before or during a tourist trip) or to choose other forms of compensation. Upon termination of the contract on the provision of tourist services in connection with the occurrence of these circumstances, the tourist/customer is refunded an amount proportional to the cost of non-provided tourist services.». Such legislative innovations ensure a fair balance between the interests of tourism entities and the more vulnerable party to the contract - the consumer of tourist services.

\section{Legal consequences of waiver of the contract on the provision of tourist services}

In accordance with Part 3 of Art. 651 of the Civil Code of Ukraine in case of waiver of the agreement in full or in part, if the right to such a waiver is established by contract or law, the agreement is terminated or changed accordingly (Law No. 435-15, 2003). Therefore the consequences of the refusal of the contract on the provision of tourist services depend on whether the refusal was complete or partial. Partial refusal of the agreement causes a change of its terms, while a complete refusal leads to the termination of the obligational relationship. In the latter case, the debtor is released from the obligation to fulfill obligations in kind.

Termination of the contract on the provision of tourist services as a result of its waiver not only terminates the rights and obligations of its counterparties, but also entails the occurrence of other special legal consequences designed to protect their subjective rights and interests.

In case of termination of the agreement on the provision of tourist services at the initiative of the tour operator, he is obliged to fully reimburse the customer (tourist) for damages caused by the unilateral termination of the contract.

The tourist has the right to waiver of the contract unilaterally, provided that the tour operator pays the costs associated with the provision of tourist services or with the preparation for their provision. At the same time, it should be noted that the costs of the tour operator must be determined by his actions to fulfill the contractual obligations, as well as documented. Only if these requirements are met the costs acquire the status of «actually incurred» and are subject to reimbursement.

To confirm the amount of such costs, the tour operator may submit agreements concluded with direct providers of tourist services, provide documents proving payments to third parties for booking in the name of a particular tourist, including payment of penalties to these parties for cancellation of a hotel reservation, return of tickets, etc. When determining the amount of actual costs incurred, it is necessary to proceed from whether they are necessary for the execution of the contract on the provision of tourist services.

In addition, it should be noted that the tour operator, having received notification from the tourist about the waiver of the agreement, may conclude a new agreement on the provision of tourist services with other persons, thereby minimizing their costs. Of course, this fact should also be taken into account when determining the amount of actual costs. Article L211-14 of the French Tourism Code (Law No. 92-1341, 1992) stipulates that when calculating the amount of costs reimbursed by the traveler for the termination of the contract, the amount of savings and income received by the tour operator from the re-provision of travel services is deducted. We consider it appropriate to implement this regulation in national law, supplementing Part 10 of Art. 20 of the Law of Ukraine «On Tourism» with the following sentence: «If after the tourist's waiver of the contract tour operator (travel agent) sells this tourist product to another customer, when determining the amount of actual costs, the amount of savings and income received by entity that sells the travel product from the reconclusion of the contract is deducted».

The tourist must apply to the tour operator for a refund, as this is the entity that sells the travel product, while the travel agent only acts as an intermediary between the executor and the customer, selecting and booking the tour. In view of this, intermediaries are not reimbursed for any actual costs.

Contractual practice abounds with examples of the inclusion by tour operators in the agreement terms about the collection of interest penalties from tourists for unilateral refusal of the contract (up to 100 percent of the tour cost depending on the waiver period), the use of which is explained by the need to reimburse costs (EXPRESSVOYAGE, 2021). 
In our conviction, the agreement terms about collecting from the tourist part of the money paid under the contract, in the form of a fixed amount, including as a percentage of the cost of the service, are contrary to the provisions of Art. 20 of the Law of Ukraine «On Tourism» and legislation in the field of consumer protection (Article 18 of the Law of Ukraine «On Consumer Rights Protection» (Law No. 3161-IV, 2005)), as they are unfair and restrict the rights of tourists as consumers of tourist services.

Tour operators unreasonably consider the waiver of the contract as a violation of the tourist's obligation. The following judgments lead to such a conclusion.

A fixed interest rate as the amount of reimbursement of expenses actually incurred is by its nature a penalty, which must be applied in the manner prescribed by law as a measure of liability for breach of obligation by the party, in proportion to the consequences of its violation (Article 549 of the Civil Code of Ukraine).

Instead, a waiver of an contract, as we have found, is a lawful act of one of the parties and therefore cannot be construed as a breach of an obligation. Refusing services, the tourist exercises his right to unilateral refusal of the agreement, regulated by Article 20 of the Law of Ukraine «On Tourism».

The legislative level does not provide for the possibility of collecting a penalty (fine) from a tourist in case the latter refuses of the contract, the only consequence for the tourist is the obligation to reimburse the tour operator for the actual costs incurred. That is, the tourist has the right to withdrawal from the contract without applying any sanctions to him.

Moreover, it is impossible to determine in advance in agreement the amount of actual costs incurred in case of refusal of the customer to execute the contract, because it is unknown when the tourist will declare such a waiver and what costs will be incurred by the tour operator till that moment.

Establishment of strict obligations for the tourist, disproportionately large amount of the fine, veiled under «reimbursement of actual expenses», without establishing the obligation of the tour operator to document them, indicates the existence of a significant imbalance of contractual obligations in favor of the entity that sells the travel product, which violates the rights of the tourist as a vulnerable party to the agreement, the importance of protecting the interests of which has been repeatedly emphasized by experts (Sanches Lima, 2018).

\section{Conclusions}

On the basis of the conducted research we reach the following substantiated conclusions.

The institute of waiver of the contract on the provision of tourist services is one of effective mechanisms of protection of the rights and lawful interests of participants of tourist relations. By its legal nature, the refusal of the agreement is a unilateral legal act, for which the unilateral expression of the will of one of the parties is sufficient, and the consent of the counterparty to change or terminate the agreement is not required. Both the customer (tourist) and the executor of tourist services (tour operator) have such subjective right.

Unilateral waiver of the contract is a measure of operational influence, ie a way of self-defense, and a means of protection of civil interest, which the party to the contract can use both in case of breach of obligations by the counterparty and when the refusal is not related to breach and any other circumstances (unconditional waiver).

The grounds for lawful withdrawal from the tourist services agreement should be differentiated into legal and factual.

A party to an contract on the provision of tourist services may exercise the right to refuse only in cases established by contract or in the presence of certain circumstances specified in the law. The mechanism for exercising of this civil right includes the following elements: out-of-court procedure for changing or terminating a contractual obligation; the party who execute waiver of the agreement notifies the counterparty by sending a notice in written (electronic) form; the contractual relationship is considered changed or terminated from the moment of receipt of the notice by the other party.

In the context of the COVID-19 coronavirus pandemic, the tourist must be able to exercise one of the following rights at his/her own discretion: to refuse a tourist trip without compensating the tour operator and to return all funds for the unprovided service; to postpone the date of travel to another date; or choose other forms of reimbursement offered by the tour operator.

The consequences of waiver of the contract on the provision of tourist services are divided into 


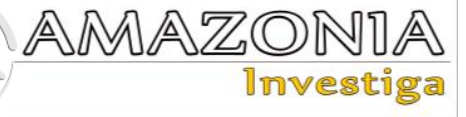

general and special. The general consequence is a change or termination of the obligation relationship, depending on whether the refusal was partial or full. A special consequence of the refusal of the agreement by the tour operator is the full compensation of the tourist losses, and the customer - the payment to the tour operator actually incurred and documented costs associated with the provision of travel services or in preparation for their provision.

\section{Bibliographic references}

Baranova, L. M. (2015). One-sided waiver of obligation as method of unjurisdiction form of defence of equitable civil rights. Theory and Practice of Jurisprudence, 2(8). Recovered from http://nbuv.gov.ua/UJRN/tipp_2015_2_11

Bodnar, T. V. (2012). The One-sided refuse in contractual obligations. University scientific notes, 1 (41), 232-241. Recovered from file:///C:/Users/User/Downloads/Unzap_201 2_1_30\%20(3).pdf

De Berti Jacchia Franchini Forlani Law Firm (2020, April, 14). Coronavirus. Cancellation of travel packages and the balancing of remedies to keep the tourism industry alive in Italy and France. Recovered from https://www.dejalex.com/wpcontent/uploads/2020/04/ArticoloCoronavirus-Tourism.pdf

Directive No. 2015/2302. On package travel and linked travel arrangements. Official Journal of the European Union, November 25, 2015. Recovered from http://data.europa.eu/eli/dir/2015/2302/oj

European Commission (2020, May, 13). Tourism and transport package. Recovered from https://ec.europa.eu/commission/presscorner /detail/en/QANDA_20_870

EXPRESS-VOYAGE (2021). Contract on the tourist services. Recovered from https://cruisexpress.com.ua/upload/images/F iles/dogovor_tourist_ready.pdf

Grinyak, A. B. (2013). Theoretical principles of legal regulation of contractual obligations in civil law of Ukraine. Kyiv: Research Institute of Private Law and Entrepreneurship of the Academy of Legal Sciences of Ukraine, Kyiv, Ukraine. ISBN 978-966-139-006-4

Grynko, R. V. (2014). Withdraw from the contract as a measure of the operational impact of a binding relationship. Scientific Bulletin of Uzhhorod University. Series «Law», 28(1), 115-118. Recovered from file://C:/Users/User/Downloads/nvuzhpr_20 14_28(1)_30\%20(1).pdf
Kharytonov, E., Kharytonova, O., Tkalych, M., Bolokan, I., Samilo, H., \& Tolmachevska, Y. (2021). Intellectual property law in the field of sports: specifics of manifestations and features of legal regulation. Cuestiones Políticas, 39(69), 530-546. https://doi.org/10.46398/cuestpol.3969.33

Kokhanovskyi, V. O. (2018). Obligations in the sphere of tourism. (PhD dissertation). Taras Shevchenko National University of Kyiv, Kyiv, Ukraine. Recovered from http://scc.univ.kiev.ua/upload/iblock/4dd/dis _Kokhanovskyi\%20V.O..pdf

Law No. 435-15. Civil Code of Ukraine. Bulletin of the Verkhovna Rada of Ukraine, Kyiv, Ukraine, January 16, 2003. Recovered from https://zakon.rada.gov.ua/laws/show/435$15 \#$ n 1220

Law No. 2909. Civil Code of the Federal Republic of Germany. Federal Law Gazette (Bundesgesetzblatt), Bonn, Germany, January 2, 2002. Recovered from https://www.gesetze-iminternet.de/bgb/BJNR001950896.html

Law No. 92-1341. French Tourism Code. Legislative part. Official Journal of the French Republic, Paris, France. December 23, 1992. Recovered from https://www.legifrance.gouv.fr/codes/id/LE GITEXT000006074073/

Law No. 324/95-BP. On tourism. Bulletin of the Verkhovna Rada of Ukraine, Kyiv, Ukraine, September, 15, 1995. Recovered from https://zakon.rada.gov.ua/laws/show/324/95$\%$ D0\%B2\%D1\%80\#n291

Law No. 3161-IV. On Consumer Rights Protection. Bulletin of the Verkhovna Rada of Ukraine, Kyiv, Ukraine, December 1, 2005. Recovered from https://zakon.rada.gov.ua/laws/show/102312\#Text

Legislative decree No 62. Official Journal of the Italian Republic, Roma, Italy, May 21, 2018. Recovered from https://ec.europa.eu/info/sites/default/files/tr anslation.pdf

Lukasevych-Krutnyk, I. (2019). Unilateral refusal refusal of transportation contracts as a consequence of violation of contractual conditions. Entrepreneurship, Economy and Law, 2, 30-35. Recovered from http://pgpjournal.kiev.ua/archive/2019/2/7.pdf

Maikut, K., Andrusiv, U., Yurkevych, Y., Dutko, A., \& Zaiats, O. (2020). Protection of the right to property in the case law of the European court of human rights. Amazonia Investiga, 9(28), 497-507. DOI: 10.34069/AI/2020.28.04.54 
Polnyi, D. (2020). Measures of operational influence applied by the parties to the lease agreement in the performance of their obligations at the expense of the counterparty. Actual problems of law, 4(24), 103-111. DOI: 10.35774/app2020.04.103.

Sanches Lima, M. G. (2018). Traveller Vulnerability in the Context of Travel and Tourism Contracts: A Comparison of Brazilian and EU Law. Cham, Switzerland: Springer. DOI: 10.1007/978-3-319-98376-9

Spasibo-Fateeva, I. V. (Ed.). (2021). Civil Code of Ukraine: scientific and practical commentary. V. 2: Objects. Legal acts. Representation. Terms and conditions. Statute of limitations. Personal non-property rights of an individual. Kharkiv: ECUS. ISBN 978-617-7934-03-4

Urazova, A. A. (2015). Category of waiver in the civil law of Ukraine. (PhD dissertation). Yaroslav Mudryi National Law University, Kharkiv, Ukraine. Recovered from http://nauka.nlu.edu.ua/download/diss/Urazo va/d_Urazova.pdf

Yavorskyy, R. I. (2015). Tourist services agreement. ( $\mathrm{PhD}$ thesis). Kyiv Institute of the State of Law named after V. M. Koretskiy NAS of Ukraine, Kyiv, Ukraine. Recovered from http://idpnan.org.ua/files/yavorskiy-r.i.dogovir-pro-nadannya-turistichnihposlug.doc. 